plant science to study such subjects as absorption of ions by leaves, uptake of minor elements, photosynthesis and sap movement in trees. The use of isotopes in animal science fell approximately into four categories, namely, intermediary metabolism, mineral metabolism, endocrinology and reproduction.

The fact that the genetic materials-the genes and chromosomes-are highly sensitive to ionizing radiations which induce hereditary changes or mutations has led to the exploration of the possibility of using this technique in improvernent of crops. So far the method has been little used in animal breeding. 'The delegations indicated that useful mutations of cereals and other crops were being obtained.

The Group also discussed the reports which several countries presented on the use of radiation in the preservation and processing of food. This work is still in the developmental stage, and important problems need further investigation. At the moment, the destruction of insects in stored products, the suppression of sprouting in potatoes and root crops and the treatment of some fresh meats would appear to be the most promising applications of ionizing radiation to foods.

The nature of the financial provisions required for research programmes involving the use of isotopes and radiation was discussed, and the delegations made statements on the scope of training facilities for isotope research. Consideration was also given to the design and equipment of isotope laboratories for agricultural research. Attention was directed to the need for an international list of available labelled compounds. For the future, the Group agreed to continue its activity in organizing special meetings or symposia in particular aspects of soil science, plant science, plant breeding, animal science and use of radiation in food preservation.

E. C. Humphries

\section{SCHOOL NATURAL HISTORY SOCIETIES}

$\mathrm{T}$

HE value of voluntary societies to the corporate life of the school and its fuller development is well brought out in three recent reports. The first, from Blundell's School, gives details of special Sunday evening lectures which are arranged by the Science Society and to which speakers of distinction have been invited over a period of many years. The hundredth of the meetings was celebrated during the year under review when the Society proudly welcomed back Mr. W. H. Dowdeswell, who had had much to do with the Society's foundation.

The role of the society in stimulating the pursuit of knowledge and truth for their own sakes is shown by the original investigations which form the bulk of the report. J. H. Becket describes observations made on catches in moth traps placed at ground-level and at a height of $80 \mathrm{ft}$. An account of experiments to compare soil temperatures under glass and polythene eloches with that of unprotected soil is given by W. L. Slater, while investigations of the flora of the Grand Western Canal are cxamined by C. Little. How woodlice maintain themselves in a moist environment has been investigated by A. J. S. Wearing; A. Lamb gives an account of the effieiency of the pollination mechanism in Arum maculatum. There is also a description of pollen and pollination in rhododendrons by A. Ridge.
Much of the report of the Rugby School Natural History Society is taken up with an account by J. A. D. Hope of his ornithological observations on the Isle of May for a short period in 1956. Hope was primarily concerned with records of the plumage and characteristics, voice and behaviour of the shag, the kittiwake and the fulmar; his essay is not unworthy of much more experienced ornithologists. Besides details of special lectures, the report contains information about the activities of the many sections comprising the Society. These include the museum, vivarium, library, zoological and entomological section ; wffiliated sections, the proceedings of which are described, include architecture, meteorology, photography, astronomy, railways, wireless, aeromodelling and philately. The Society has much to be proud of.

This is also true of the Oundle School Natural History Society, the report of which is mainly eoncerned with records of mammals, birds, fish, butterflies and moths, dragonflies, rotifers, crustaceans and plants observed in the neighbourhood of Oundle. An interesting account of laboratory animals shows that axolotls, African clawed toads, stick insects, salamanders, eyed lizards and geckoes, various British lizards and tropical fish were all under observation some time during 1956.

\section{OXFORD BOTANIC GARDEN}

$T$ HE Botanic Garden at Oxford, which is the oldest in Britain, was founded and endowed as a Physic Garden by the Earl of Danby in 1621 . The Garden was intended for "the improvement of learning" with special regard for the study of 'simples' or drug plants. It was laid out on the site of the old Jews' burying ground opposite Magdalen College, from which the Garden is still leased by the University.

In 1642 the Garden was ready, and Danby, having failed to secure the services of the King's gardener, John Tradescant, appointed Jacob Bobart, an old Brunswick soldier, as 'Keeper'-indeed, as 'Hereditary Keeper'. During the difficult years that followed, Bobart began to collect garden plants, mainly for their interest in medicine, and in 1648 he published a catalogue of 600 native British plants and twice as many from abroad.

A professor of botany was appointed by Charles II in 1669 but the post was not endowed, and the care of the Garden and even the duties of teaching largely lay in the hands of Bobart and later of his son; the younger Bobart made some of the first experiments on sexual reproduction, using male and female plants of the indigenous campion. Many of the plants that he cultivated, especially West Indian ferns, are probably growing in the Garden to-day.

Fifteen years after the death of Bobart a chair of botany was finally endowed by William Sherard. The new professors followed the custom of the century rather than the example of Bobart : teaching ceased. The herbarium grew, but the plants were neglected. In these circumstances, it was by instinct rather than by instruction that Gilbert White, the naturalist, and Sir Joseph Banks, who later founded and stocked the gardens at Kew, visited the Physic Garden as undergraduates and gained a not too favourable impression of botany as a systematic study. 
More than a hundred years passed and the Garden was then put in charge of an energetic and versatile man who had new ideas about many things, including plants and gardens; in 1834 Charles Daubeny became professor of botany. He changed the name to Botanic Garden. He rebuilt the glasshouses and he replanned the beds. He made new collections of plants in their economic, historical and geographical relations, and he raised trees from seed sent to him by collectors in America, India and China, trees which may still be seen in the garden. He wrote a Guide to the Garden which appeared in three editions, built an official residence for the professor next to the Danby Gate, and he set up a fountain and two aquaria. One of Daubeny's activities reached out to a larger and later world. On the land adjoining the river, he laid out experimental plots designed to show the value of mineral fertilizers. Their effect was to inspire one of his pupils, John Lawes, to found what is now the Rothamsted Experimental Station. Daubeny gave the place a new name, and he also gave it a new purpose.

The past hundred years have seen another kind of transformation in the character of the Garden. It has been during this time that, by breeding wild plants and selecting their progeny, our modern garden flowers have been created. The wild parents were largely the 7,000 exotic species brought into our botanic gardens during the reign of George III, or more precisely, during the life of Sir Joseph Banks. In one year, I789, there arrived in the Port of London Rosa chinensis and Chrysanthemum indicum, the parents of all our modern roses and chrysanthemums. The new plants are represented by these and by all the asters and dahlias, irises and narcissi of our outdoor gardens, the begonias, pelargoniums, fuchsias and orchids of our glasshouses. The result of this new experimental horticulture can be seen in any flower show. In the Botanic Garden the stages in its history, which are quickly lost and forgotten elsewhere, are carefully and fortunately preserved.

An account of the Garden as it exists to-day has been prepared by the keeper, Prof. C. D. Darlington, and the superintendent, G. W. Robinson*. It contains details of the more interesting plants, when they were planted, and where they came from. All botanists would be glad to possess it.

\section{T. H. Hawkins}

* Oxford Botanic Garden. Pp. 48. (Oxford: Basil Blackwel], 1957.) $2 s .6 d$

\section{ADAPTIVE RADIATION OF TRAPDOOR SPIDERS}

$\mathrm{T}$ HE spiders of the tribe Aganippini show a striking sequence of adaptation to habitats ranging from moist forest situations to desert environments. These have been investigated in Western Australia by Barbara Main (Austral. Mag., 12, No. 5; March 1957).

The aganippinid spiders show a sequence of adaptation, represented by three dominant levels corresponding with a change from a moist to a dry environment. Associated with the change in habitat the spiders exhibit two main lines of adaptation. The first is associated with the reduction of water loss through the cuticle and the second is directed towards a more efficient feeding method when food is sparse. A thick abdominal cuticle, possessed by certain species, prevents loss of moisture from the body. Idiosoma nigrum, for example, has a tough, spiny, sclerotized abdomen in contrast to the soft, hairy abdomen of Aganippe latior.

Spider's which live in habitats having an abundant food-supply, such as the moist situations of litter formed from the wide flat leaves of such trees as eucalypts and banksias and which have the burrow opening among the litter, seize their prey from within reach of the burrow entrance but without emerging. Similarly, spiders occupying creek banks and claypans seize prey within reach of the burrow. Spiders in dry environments, however, such as the dry habitats around the bases of casuarinas and acacias, have a different technique of prey capture. These animals collect twigs and attach them singly, with silk, in radial arrangement, to the rim of the burrow. The twigs are then used as 'feeling-lines' for detection of prey. Spiders have been observed sitting in the burrow with the tips of the legs on the rim-ends of the twigs. Movements of insects on the twigs stimulate the spiders to run out of the burrow along the twigs in pursuit; in this way the spider greatly increases the area from which it can obtain prey.

Associated with the different methods of feeding, which varies in the distinct habitats, there are certain types of structure which represent three adaptive levels. The 'moist-dwelling' spiders have the head raised and sloping in such a way that the small, widespread eyes are directed only to the front. The poor eyesight of these animals is associated with the fact that in the litter they would be unable to see prey at any distance. Such animals also have short stout legs, adapted for supporting the thickset body within the burrow.

Spiders inhabiting bare-ground situations have moderately enlarged eyes, which is associated with seeing their prey in the open. The legs of these spiders are slightly longer and thinner than 'moist-dwelling' spiders; this is advantageous for quick movement partly outside the burrow.

'Twig-lining' animals have a flattened carapace enabling the eyes, which are greatly enlarged, to see in all directions. This is of great advantage when pursuing prey for some distance from the burrow. The legs are long and slender, adapted for running quickly on the flat surface outside the burrow.

Not only are the behaviour and body structure of the animals modified in adaptation to the different habitats, but they also construct different and characteristic types of doors to the burrows. Dwellers in moist habitats have thin, fragile doors made of silk-bound litter fragments. Those in open situations have soil doors; if in creek banks, the doors are thin and flaplike, whereas in claypans doors are thick and cork-like. Such a cork-like plug prevents the burrow being flooded when the bare ground is inundated after rain. Finally, 'twig-lining' spiders, which run out of their burrows to eatch prey, construct thin, wafer-like doors of litter fragments that are very light in weight and stand open unsupported when flung up as the animal pursues its prey.

It is interesting that the various species, representing different adaptive levels, have apparently been derived from a common ancestor by its expansion into several types of habitat, where genetic recombination and natural selection have operated to produce forms which are modified, behaviourally and structurally. 